\title{
A CONCEPTUAL FRAMEWORK FOR THE ALIGNMENT OF INNOVATION AND TECHNOLOGY
}

\author{
R. Pellissier (I)
}

\begin{abstract}
Historically, business institutions base their growth strategies on their research and development (R\&D) function. This function is fairly established and sets out to acquire new knowledge in a systematic process of research in order to produce or improve products, services or processes. In fact, innovation and research are two of the main thrusts for economic growth. The paper explores the convergence of innovation and research from a previous paper, focusing on the development of a conceptual model in terms of the technology (or knowledge) system required for the accomplishment of this convergence. In this sense, technology is defined as knowledge, tacit or explicit, in human, document or electronic format. The proposed convergence requires the use of knowledge systems to drive the innovation and research. The contribution of the paper lies in the knowledge developmental aspects of research and innovation convergence. An existing model to achieve for knowledge systems development will be reviewed and a modified version presented after careful consideration of the body literature on knowledge and innovation systems. This model incorporates aspects of knowledge management as well as innovation and research management.
\end{abstract}

Keywords:Technology, innovation, alignment of technology and innovation

(I) Department of Business Management, University of South Africa. Pretoria, South Africa.pellir@unisa.ac.za; 


\section{Introduction}

The unprecedented economic growth in a country can primarily be attributed to innovation (Ravichandran). Increasing complexities, resource scarcity and rising customer expectations leave little choice other than to develop innovation capabilities.

Innovation is not an option today. This interest in innovation is confirmed by a McKinsey study that asked over 750 CEOs of the world's largest and most respected firms, 'What's the extent of change that you need to make in the next 2 years?' The CEOs responded that they knew that innovation was important, but $65 \%$ of the CEOs said they were planning significant change over the next 2 years, and another $22 \%$ said they planned to implement moderate change. More importantly, when the CEOs were asked 'What's your past level of success in managing significant change?' only 15\% said they had been 'very successful.' Another 15\% said they had had 'little or no success' interest in innovation is being spurred by radical change and disruption that is going on in the business environment. Indeed, almost $50 \%$ of the CEOs surveyed said the source of innovation was from changes in the business environment. Less than $20 \%$ reported that innovation came from internal R\&D.

Disruptions in the business environment cause economic shifts that destabilize industries, companies, and even countries. They allow new entrants or forward-thinking established players to introduce innovations (in products, services or processes) that transform the way companies do business or consumers behave. Successful innovators take ideas and turn them into opportunities by adding a business model that creates sustainable economic value for all stakeholders. They then go one step further and exploit the opportunity by creating a sustainable business. One might ask how they accomplish this. One answer may be the natural talent towards risk and opportunity. Another possibility might be that they recognise the value of their technologies and exploit these. This paper will deal with the second possibility.

In a previous study, the convergence of innovation and research was examined (Pellissier). The premise under investigation was that that innovation and research should and can, converge under certain conditions. A model was presented to achieve these using different forms of knowledge. With knowledge (or technology) being the drivers for innovation and research convergence, the objective of this paper is to develop a technology system to ensure innovation and research convergence. This will be achieved by careful review of the body literature on innovation and knowledge systems in order to formulate a technology system to advance innovation activities that incorporate research outcomes and other forms of knowledge created.

\section{Technology and technology systems}

Contrary to the general view, technology is not a machine, although it is true that technological product innovations could be classified as such. This (the machine view) gives limited application to technology and makes it more static than it can be. Simon (in Davis, Hands, \& Mloki), states that technology is '.. knowledge that is stored in millions of books, in hundreds of millions or billions of human heads, and, to an important extent, in the artefacts themselves'. McGinn notes that ' ..[technology] is the human activity which is devoted to the production of technics - or technics-related intellectual products - and whose root function is to expand the realm of human possibility'. In these definitions, technology relates more to knowledge and human activity, than to machines or technics. Burgelman, Christensen and Wheelwright believe that ' .. [technology] refers to the theoretical and practical knowledge, skills and artefacts that can be used to develop products and services as well as their production and delivery systems.' They (Burgelman, et al.) propose that the key elements of technology may be implicit, thus existing only in embedded form. However, they then claim that technologies are usually the outcomes of development activities that put inventions and discoveries to practical use. To this end, they list examples of technics (the transistor, integrated circuits and microprocessors) to demonstrate this point and use tangible products to illustrate socalled technological innovations (disposable diapers, computers and fuel injection). Their paradoxical view of technology does not seem to address the significant difference between technics and technology. This paper will use the wider definition of technology as stated by Simon, referring to knowledge.The conflicting innovation application between technics and technology will be discussed in the section on innovation and innovation systems.

According to Polanyi there are two main dimensions of knowledge: the epistemological and the ontological. He explains that epistemological knowledge can be tacit or explicit. Tacit knowledge is personal and intuitive and is entrenched in values, ideals, routines and emotions, i.e. our mental models of the world. Although subjective and difficult to transfer, it does contain technical components. Explicit knowledge can be expressed in verbal or written format and is thus transferred easily. Ontological knowledge originates in individuals, teams, organisations or between organisations. The focus is on the individual as the basis or creator of knowledge. Nonaka \& Takeuchi model knowledge creation as the interplay between tacit and explicit knowledge and the interaction between socialisationexternalisation-combination-internalisation (known as the SECl process) (Nonaka \& Takeuchi). Through socialisation or conversions from tacit knowledge to tacit knowledge, experiences are shared and mental models and technical skills created. Sal- 
mador \& Bueno use these dimensions to present knowledge flows in the strategy formulation process and to study the main theoretical and practical implications for the development of a knowledge system.

\section{Strategic advantage of technology}

Knowledge, and the ability to use that knowledge, certainly provides competitive advantage (Laudon \& Laudon). Hamel \& Prahalad and Lowendahl \& Revang are amongst many authors who maintain that the strategic advantage in knowledge is its ability to acquire, integrate, combine, store, share, apply and create. These knowledge actions can briefly be summarised as follows (Laudon \& Laudon), P (I) Capture \& codify knowledge: artificial intelligence, for example expert systems, neural nets, fuzzy logic and genetic algorithms; (2) Create knowledge: knowledge systems, for example: CAD, virtual reality and investment workstations; (3) Share knowledge: group collaboration systems, for example groupware and intranets and (4) Distribute knowledge: office automation systems, for example word processing, desktop publishing, imaging, electronic calendars and desktop databases.

Hedlund \& Nonaka distinguish between the storage of knowledge (as a stock), the transfer of knowledge (as a flow), and the transformation of knowledge (as interaction). Venkatraman, Henderson, \& Oldach initiated work on aligning an organisation's corporate and business strategy to its technology strategy. They differentiated between the strategic component (focusing on the dominant business model) and the corresponding operational requirements to make this happen. Neef identifies six strategies and techniques to retain competitive advantage. His strategies use technology as knowledge or as technics: (I) Adopt a knowledge-based strategy; (2) Utilise a knowledge-based process plan; (3) Develop a knowledge-based culture; (4) Adopt an appropriate technical support structure; (5) Focus on knowledge stewardship and (6) The development of a corporate memory system.

\section{Innovation and innovation systems}

The technology-based economy is reflected in the shift from scientific and technology based innovation processes to new forms of knowledge creation which are to a lesser degree dominated by technology (Gibbons, Limoges, Nowotny, Schwartzmann, Scott, \& Trow). This understanding of innovation discussed within the framework of a knowledge-based economy goes far beyond the linear or chain linkage models that have long been used in innovation theory to explain innovation processes in high-tech industries (Strambach). Innovation is to be understood as the result of cumulative dynamic interaction and learning processes involving many stakeholders. Here innovation is seen as a social, spatially embedded, interactive learning process that cannot be understood independently of its institutional and cultural context (Braczyk, Cooke, \& Heidenreich; Lundvall; Freeman).

An innovation constitutes ' .. a new or innovative idea which is applied to initiating or enhancing a product, service or process' (Hivner, Hopkins \& Hopkins). Rogers noted that the main elements in the classical model of the diffusion of new ideas are the innovation, defined as an idea, practice, or object perceived as new by an individual or other relevant unit of adoption, which is communicated through certain channels over time among the members of a social system. Since Roberts' definition [of innovation] maintains that an innovation can only be seen as innovation if it is has implementation and commercial value, it is important to measure the impact of innovation. Ravichandran believes that measuring the impact of innovation activities will depend on (I) the typology, (2) the degree of departure from the preceding product, service or process, (3) the extent of usefulness of the innovation and, (4) the volume of profitability generated.

While the technological [and technical] innovations are essential for the business operations, the accompanied organisational [and leadership] innovations are critical for the long-term growth and sustainability (Snow \& Hrebiniak; Thomas) The literature is at least confusing on differences between forms of innovation in relation to technology. The following definitions are posited: (I) Technical innovation - the use or application of the technology (for example social networking as a technical innovation using the internet as a technology via cell phone as a technology or a PC as a technology via WiFi as a technology); (2) Technological innovation - the technology itself (this can include the product, method, process etc., for example technology as knowledge to enable (Open source, Linux, Ubuntu, Internet, e-mail,WiFi or a physical product: iPod, the space shuttle, a machine gun, cell phone,WiFi or Blue Tooth); (3) Organisational innovation - the processes, systems, strategies or organisation design (for example Dell, e-Bay, Skype, Open source innovation (P\&G), total quality management, 6-Sigma, but limited to operational elements within an organisation) and (4) Leadership innovation - the ability to affect human behaviour to accomplish some mission and vision.

Strambach suggests that the interdisciplinary view of innovation systems is concerned with understanding the general context of the generation, diffusion, adaptation and evaluation of new knowledge which determines innovativeness. It follows 
that the focus is on non-technical forms of innovation as defined above. Common characteristics of the different approaches to innovation identified by Edquist include (I) innovation and learning at the centre, (2) a holistic and evolutionary perspective, and (3) an emphasis on the role of institutions. The increasing interdependence of technological and organisational change is a significant feature of systems of innovation, which means that technological innovation and organisational innovation have become increasingly important. These are combined with more diverse knowledge requirements which include not only technical know-how, but also economic, organisational, and sociological knowledge and competencies. The second reason for the increased interest in non-technical innovations is associated with the connection between the organisational innovation and the corresponding learning capacity. The acceleration of change that is part of the globalisation process means that organisational learning processes are more and more important for creating and maintaining competitiveness.

Ultimately, whether innovation is successfully diffused, requires some absorptive capacity on the part of the target audience. Cohen \& Levinthal define absorptive capacity as '... the ability of a firm to recognise the value of new, external information, assimilate it and apply it to commercial ends.' The diffusion of the innovation is normally dependent upon the specific innovation typology, the innovation champions, the time element to successful diffusion and the absorptive capacity of the adopters. Schnepp, Bhambri, \& Von Glinow define technology transfer as a process whereby the knowledge is passed from one entity to another. This process involves the dissemination of documentation describing the technology, the training (called software) to transmit the knowledge and the transfer of the equipment, components or raw materials (called hardware). Gee maintains that technology transfer is the application of technology to a new use or a new user. Thus technology transfer links the existing technology base and the innovation process in order to increase productivity.

\section{Strategic advantage of innovation}

There is no doubt that innovation has become a core driver for growth, performance and valuation. Although there are no best practice solutions to seed and cultivate innovation, Barsh, Capozzi and Davidson identify three building blocks for innovation: (I) formally integrate innovation into the strategic management agenda (thus innovation is managed, tracked and measured as a core element of the organisation's growth); (2) Create conditions that allow dynamic innovation networks to emerge and flourish and (3) Take explicit steps to foster a culture of innovation by valuing ideas and collectively overseeing risk. This is complemented by taking the following steps to advance innovation: (I) Identify the type of innovation that can drive growth and strategic objectives; (2) Add innovation to the formal agenda at regular leadership meetings; (3) Set performance metrics and targets for innovation and (4) turn selected managers into innovation leaders.

\section{Linking technology and innovation}

From the perspective of the emerging knowledge economy, an innovation concept which is primarily based on technological knowledge that in turn results in goal directed research is too narrow. Generic technological innovations are only part of the complex innovation activities even where technologies are more and more frequently integrated in products, materials, methods, and services. The relationship between science, technological change and innovation appears to have changed (see OECD). Innovation is not only restricted to the research and technology intensive segments of economies. The emerging knowledge economy is characterized by increasing innovation in non-technical areas too, especially in services and new forms of work and organisation. Quantitative and qualitative shifts in the demand and need for knowledge are a major result of the increasing importance of these non-generic technological innovations, that is, innovations that are not directly linked with technological scientific content.

The notion of technology as knowledge also affects innovation. Smith believes that all innovation requires two distinct types of knowledge. These are:

Component knowledge: This is knowledge about each of the components that perform a well-defined function within a broader system that makes up the product.

System knowledge:This is knowledge about the way the components are integrated and linked together.

These types of knowledge lead to a typology of four different types of innovation:

Incremental innovation: Incremental innovation groups together those products that have been changed by improving the components. These are not changes to the products but only improvements of the components that already exist (for example changes to packaging).

Radical innovation: This is a whole new design of the product. This entails the use of a new set of components that are linked together in a new architecture (for example the iPod). 
Modular innovation: Modular innovation uses the design and architecture of an existing product and then employs the use of newly designed components (for example clockwork radio).

Architectural innovation: The design and components remain the same but new linkages are used (for example the Sony Walkman).

The dynamic growth of knowledge intensive business services (KIBS) is an indication of the increasing need for trans-disciplinary application and problem oriented knowledge in innovation systems (Strambach). She continues that research into the role of knowledge in innovation processes has only just begun; nevertheless, it is already evident that KIBS have important functions in systems of innovation such as: (I) The transfer of knowledge in the form of expert technological knowledge and management know-how, (2) the exchange of empirical knowledge and best practice from different branch contexts, (3) the integration of the different stocks of knowledge and com- petences that exist in innovation systems and (4) the adaptation of existing knowledge to the specific needs of the client.

Persaud, Kuma \& Kumar maintain that research on Science and Technology (S\&T) or on Research and Development (R\&D) involve the creation and application of new knowledge. Scientific fundamental, or basic research is generally construed as the creation of new knowledge for knowledge's sake, while technological research is commonly described as the application of the results of scientific research for the creation of new products and processes. Pellissier shows that innovation is fundamentally a function of technology, research and creativity. In this regard, innovation is seen as the interrelationship between research (as planned scientific knowledge), technology (as human knowledge) and creativity (as non-linearity). This viewpoint integrates knowledge creation and distribution (in human knowledge and in planned scientific research) into the innovation mindset (see Figure I).

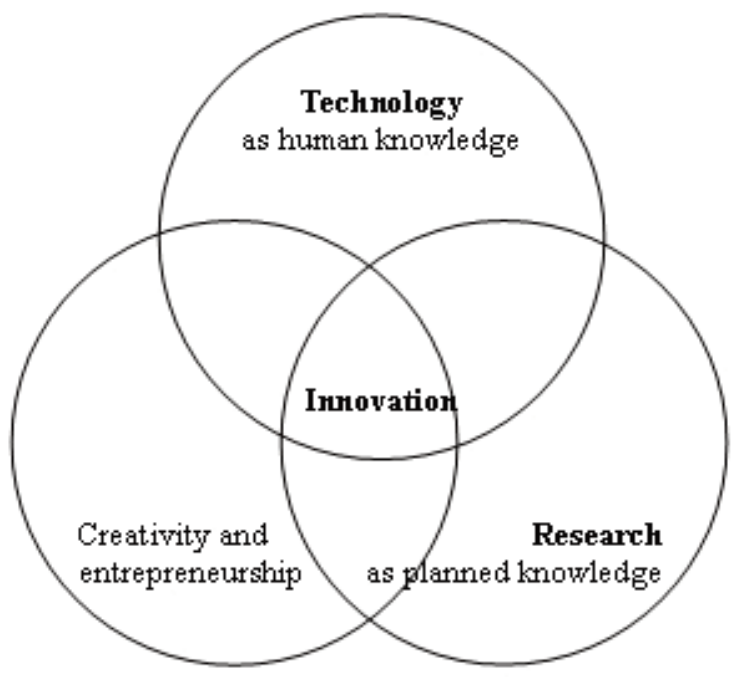

Figure I: Redefining innovation as the interrelationship between research (as planned knowledge), technology (as human knowledge) and creativity and entrepreneurship

Source: Pellissier

Wei [34] argues that S\&T research involves the creation, diffusion, and application of highly technical knowledge, some of which is explicit, some of which is tacit, and some of which is cultural. He continues that the S\&T research process is in itself complex, and greater complexity is added when highly accomplished, globally dispersed professionals from diverse cultures and speaking different languages are included. In this context, the generation, sharing, and application of new knowledge, particularly tacit knowledge, become much more challenging.

\section{Proposed technology framework to advance and aid innovation}

The quantitative and qualitative dimensions of organisational models have changed in the last decade. Not only has there been a rapid succession of different organisational models and principles, there have also been organisational innovations which go far beyond production and production-related functions. The aim of organisational innovations is no longer simply to increase the functional flexibility of the entity, but also to increase their strategic flexibility. The rapid combination and separation of whole functional areas is possible through 
decentralizing and empowering company units and functions. Restructuring of the organisation increasingly results in the breaking up of traditional structures and the fragmentation of production and service chains. New forms of organisation which are directed towards non-material interaction and communication relations within the entity and its interfaces with the environment, impact on the way the internal and external know-how resources are integrated and used. Thus the organisational learning capacity is influenced. Dosi argues that, from a long term perspective, there has been a co-evolution between organisation forms and the innovativeness of the firm.

Following on Nonaka and Takeuchi's framework for knowledge creation, Figure 2 below encapsulates the application of knowledge in the innovation process. In fact, the framework shows three types of knowledge (tacit, explicit, and cultural) that must be managed to effectively realize enhanced innovative capacity. Cultural knowledge is considered an underlying context to tacit and explicit knowledge, i.e., the way information and knowledge are perceived, created, shared, and disseminated is influenced by

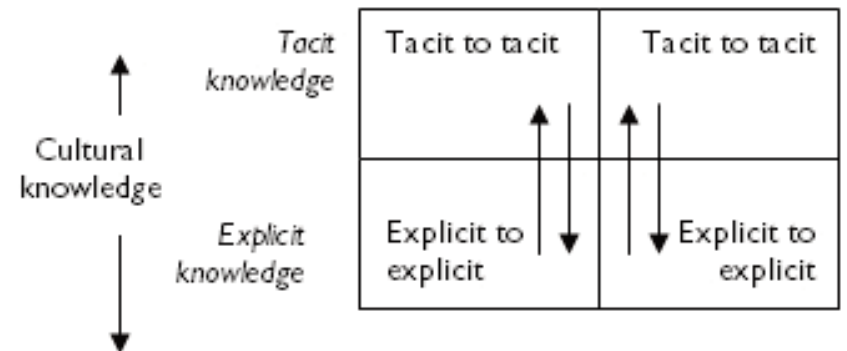

Figure 2: Model for innovation capacity using knowledge Source: Persaud, et al.,

the cultural context of the knowledge partners. The framework also indicates that innovative capacity can occur at the individual or organisational (lab) level. The focus is on the mechanisms employed to enhance innovative capacity of the labs. As suggested by Nonaka and Takeuchi, labs can enhance their innovative capacity by converting tacit knowledge into explicit knowledge (which they termed externalization) and explicit knowledge into tacit knowledge (which they termed internalization). Tacit-to-tacit and explicit-to-explicit knowledge conversions are referred to as socialization and combination, respectively. The distinction between tacit and explicit knowledge is based on the degree of codability of the knowledge. Explicit knowledge can be easily coded and transferred from person to person or from one location to another. It is easy to specify, document, and describe by formal methods. It can easily be expressed verbally, in print, graphically, or by other systems of symbols, e.g., computer programs. Examples of explicit knowledge include physical properties, geometrical forms, computer programs, and manufacturing blueprints. Tacit knowledge cannot be easily coded and transferred. It is also not easily accessible. It is the knowledge people carry in their heads, it is intuitive and experience based, but it represents a disproportionately large part of the knowledge needed to conduct cutting-edge R\&D. Cultural or situational specificity is a major component of tacit knowledge. Tacit knowledge assigns meaning to data and facts and is often inseparably linked to processes and people, representing a central element of the skills and competencies of team members (Teece, Pisano \& Shuen).
According to Hedlund and Nonaka,' .. tacit knowledge is structured more like an opera or great novel than like a house or a computer program. That is why stories, myths, great personalities, ceremonies are so important in communicating tacit knowledge'. Cultural knowledge consists of the cognitive and affective structures that are habitually used to perceive, explain, evaluate, and construct reality. It is the assumptions and beliefs that are used to describe and explain reality, as well as the conventions and expectations that are used to assign value and significance to new information (Wei). It seems fairly obvious, then, that international R\&D projects involving cross-national and multidisciplinary teams are likely to be influenced by the cultural filters team members use to create, share, and transfer knowledge. Thus, it is fairly easy for a receiver to interpret information in a way not intended by the original sender.The research by Persaud et al. show the principle categories of techniques used in their sample to create, share and diffuse knowledge within a global R\&D network. They find that generating and sharing tacit knowledge are effectively achieved through personal interactions (for example virtual project teams, job rotation and informal networks) among R\&D personnel, whilst, for explicit knowledge, the preferred mode is technologically supported media (for example intranets, Lotus Notes and Microsoft Office tools and servers). They further maintain that informal communities of practices (for example informal technology clubs and online discussions) guided by articulate project management procedures, guidelines and blue prints, facilitate the flow of knowledge from tacit to explicit and back. 
Persaud et al. use the model in Figure 2, in conjunction with the four activities with respect to knowledge (Hamel \& Prahalad, Lowendahl \& Revang): acquisition, sharing, creating and distri- buting to identify four approaches in the development of a knowledge system for innovation building (see Table I).

\begin{tabular}{|c|c|}
\hline Category & Approaches \\
\hline Identifying knowledge pools & $\begin{array}{l}\text { Informal personal contacts among R\&D managers, scientists, and engineers; } \\
\text { Exchange visits among labs' managers, scientists, and engineers; } \\
\text { Yellow pages of capability; contact lists; who-is-who lists; Knowledge maps; } \\
\text { Gatekeeper meetings; } \\
\text { Science and technology fairs; } \\
\text { Conferences, seminars, and workshops; } \\
\text { Staff exchanges; Job rotation; Social and cultural events; } \\
\text { Cross-training; Annual forums. }\end{array}$ \\
\hline $\begin{array}{l}\text { Capturing and influencing kno- } \\
\text { wledge flows }\end{array}$ & $\begin{array}{l}\text { Shared goals, mission, values, and norms; } \\
\text { Training and personnel development; } \\
\text { Appointing chief information officers and knowledge management officers; } \\
\text { Rewards and incentives; Intranets; } \\
\text { Technology clubs and associations; } \\
\text { Coordinating bodies such as cross-national committees, liaison persons, integrators, integrating depart- } \\
\text { ments or teams, overseas R\&D office, executive vice presidents for overseas R\&D, central project manage- } \\
\text { ment office, international project management office; } \\
\text { Creating international labour pools; } \\
\text { Using common development and information sharing tools; } \\
\text { Co-location of project teams; } \\
\text { Knowledge sharing sessions after participants return from a conference or an assignment involving a diffe- } \\
\text { rent project to the same project with a different team. }\end{array}$ \\
\hline Reporting knowledge & $\begin{array}{l}\text { Intranets; R\&D policies; } \\
\text { Project management manuals; } \\
\text { Job descriptions; Progress reports on projects; } \\
\text { Routine reporting on labs' R\&D activities; } \\
\text { 'Workbooks' with the specs and request for changes for a technology system; } \\
\text { Evaluating R\&D programs; } \\
\text { Controlling the flow of information; } \\
\text { Newsletters; Prototypes; Projects update meetings. }\end{array}$ \\
\hline Sharing knowledge & $\begin{array}{l}\text { Language training; } \\
\text { Intranets; Job rotation; } \\
\text { Science and technology fairs; } \\
\text { Conferences, seminars, and workshops; } \\
\text { Topic meetings; } \\
\text { Using common development and information sharing tools such as CAD/CAM, Lotus Notes, IBM Kno- } \\
\text { wledge X, Microsoft Office Tools \& Servers, etc. such as intranets; cross-national, multidisciplinary teams; } \\
\text { and liaison individuals, while only three reported using internal science fairs. }\end{array}$ \\
\hline
\end{tabular}

Table I: Categories of knowledge for innovation Source : Persaud et al. 
Persaud et al. conducted their research by sending 23I questionnaires to Canadian, American, Japanese and European high technology manufacturing multinationals, using convenience sampling. They collected both quantitative and qualitative data. Table I represents the approaches listed by the respondents. The proliferation of techniques thus identified is indicative of the fact that there seems no cohesive technology strategy, or if there is, that this has evolved in an ad hoc fashion. The respondents also agreed that personal interaction is an effective way to build trust, the latter being an important prerequisite for knowledge sharing in an R\&D environment. Furthermore, despite the fact that technology-supported media are usually used to share and disseminate explicit knowledge; such media were mostly inappropriately used. Finally, Persaud et al. conclude that generating and sharing tacit knowledge are effectively achieved through personal interactions in the R\&D environment, whilst technologically supported media is the preferred mode for explicit knowledge. Informal communities of practice, guided by specific project management, help to facilitate the knowledge flows from tacit to explicit and from explicit to tacit. The model was developed to contribute to the R\&D function and specifically the innovative capacity using formal and informal knowledge systems. The OECD continues to stress the inability to manage decentralized complex systems as an inhibitor. The Persaud et al. research is founded in the belief that innovation capacity is enhanced by collaboration (individual to collective). Finally, although identifying possible technology categories, their framework does not address the forms of innovation, nor link the technology and innovation for research and innovation convergence.

This is not the only model in existence for the development of a knowledge system. Pellissier described the following hierarchical model for knowledge sharing, capturing, distributing and reporting (see Figure 3). The model starts with (I) office automation and personal productivity tools and utilities (i.e. information communication and technology tools), continues to (2) transactional databases (database management systems), then to (3) standard systems applications (online transaction processing) and concludes with (4) business intelligence (data mining and data warehousing techniques).

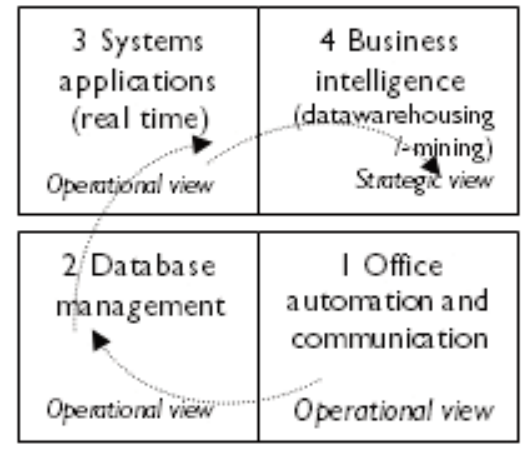

Figure 3: Classification of information needs and deliveries Source: Pellissier

The first three categories above are primarily concerned with data capturing, time saving and the achievement and communication of day-to-day efficiencies. Automation and personal productivity tools have automated the process of creating documents and organising personal information. Transactional databases provide an efficient means of storing substantial amounts of data that is continually changing. Systems applications enable an organisation to integrate its operational processes based on common software and produce real time information about any aspect of the firm. The first three categories [marked I-3 in Figure 3] are essential to the organisation's survival and provide an operational solution. However, the last category concerns more than survival. It is essential only to those organisations that have set themselves more am- bitious goals (such as market leadership, exceptional levels of customer satisfaction, above-average return and sustainable competitive advantage), hence a more strategic focus. This model adds to Persaud et al.'s perspectives by showing how the sharing, distribution, creation and coding take place. The elements in this model are linked to non-technical innovation forms.

Combining the framework of Persaud, Kumar and Kumar (Table I and Figure 2) that links knowledge creation and transfer mechanism for R\&D with the Information delivery model (Pellissier) above leads to an extended framework for the acquisition, sharing, distribution and coding of knowledge to achieve implementable innovation set out below (Table 2). 
J.Technol. Manag. Innov. 2008, Volume 3, Issue 3

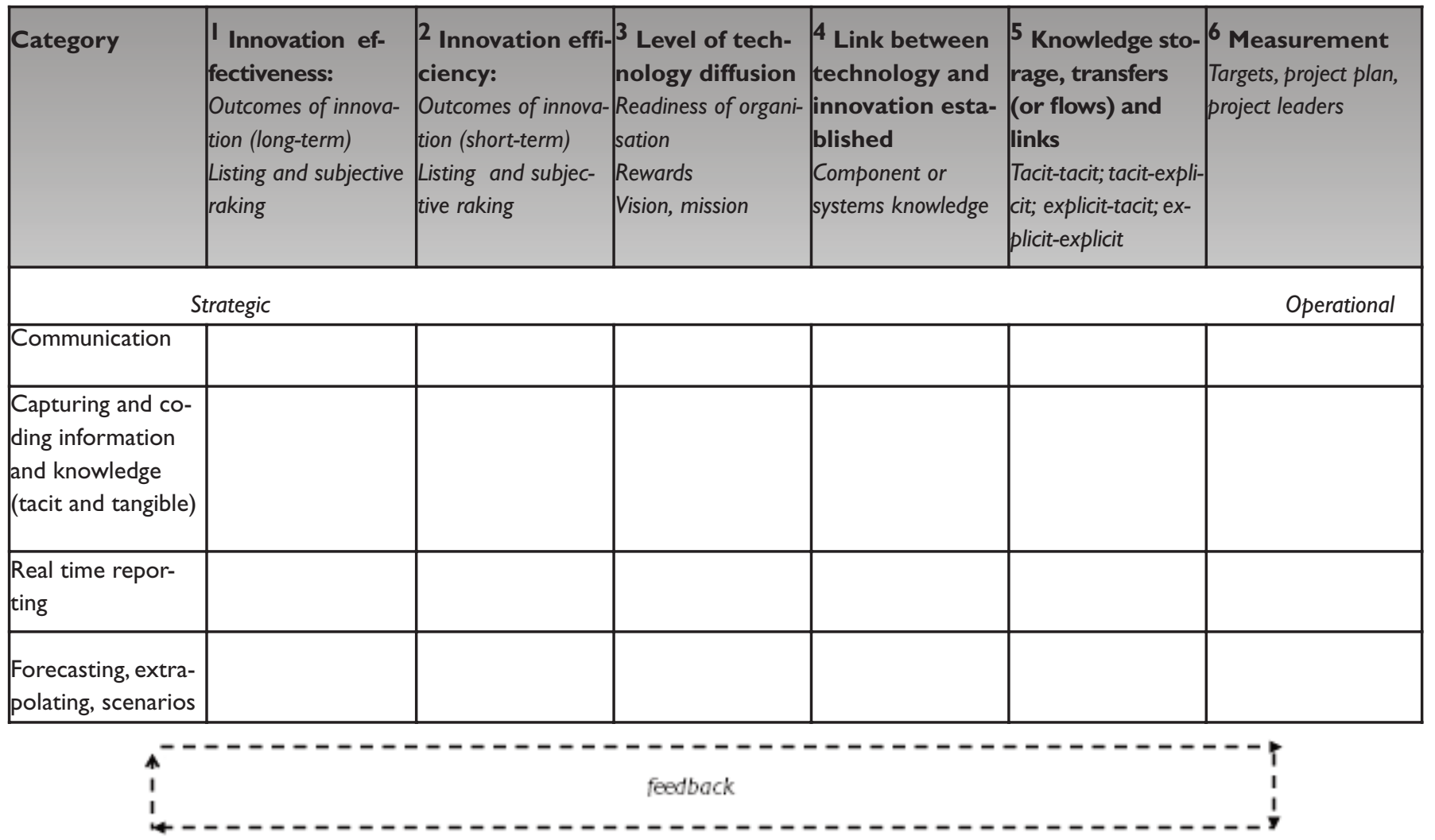

Table 2: Proposed technology framework to advance and aid innovation

The proposed model presented in Table 2 links innovation to knowledge using the typologies of innovation and the specific dimensions of knowledge to create a template of knowledge creation for the convergence between research and innovation. The cells in the template are organised from a strategic viewpoint (effectiveness perspective on the left hand side to an operational (efficiency perspective) and takes into account the different activities of knowledge (communication, capturing and coding, reporting in real time and forecasting), while acknowledging that non-technical innovation is critical in complex environments.

\footnotetext{
I Innovation effectiveness: Outcomes of innovation (long-term). Formulate strategic objectives from corporate and business strategy and link to innovation using Venkatraman's framework

2 Innovation efficiency: Formulate operations plan and link elements of plan to innovation.

3 Level of technology diffusion: Readiness of organisation. Ensure that the culture and rewards acknowledge innovation. Develop an understanding of the value of knowledge. Develop a technical and technological infrastructure.

4 Link between technology and innovation established. Differentiate between component and systems knowledge. Link to the innovation activities.

${ }^{5}$ Knowledge storage, transfers (or flows) and links: Map flows - Tacit-tacit; tacit-explicit; explicit-tacit; explicit-explicit. Identify communities of practice

6 Measurement: Ensure that the outcomes are measurable using project management. Link to reward systems. Feedback to I.
}

(R\&D) is an important one. However, this link is only valuable if there is some means, some system that can tap into the knothe requirements of some technology-based system that can provide the appropriate knowledge for the innovation to take place and be implemented. Such a knowledge system has to be based within the requirements of the innovation and the different activities attributed to knowledge. This paper used an analytical framework to derive an understanding of the technology requirements for innovation. The paper's focus was on wledge created through research and technology. This leads to 
an understanding of the contribution of knowledge, an appropriate knowledge system and the development of KIBS to ensure successful innovation. This enhances the innovation capability and ensures a better synergy between the research and development function and the degree of usefulness of the innovation - process, product or service or technical, technological, managerial or leadership.

The paper contributes to the existing literature by expanding models for innovation and research in terms of the converging technology. The research acknowledged the importance of technology in innovations and showed the dimensions of knowledge and the complexities therein to support innovation. The aim of the paper was to present the classic literature available in the field, to review a framework for knowledge and propose a framework for technology in order to enhance the innovation and research functions. Finally, the structure of the framework follows innovation typologies (strategic and operation advantages), the contribution of knowledge, the individuals and labs involved and the space for the project detail.

\section{References}

BARSH, J, Capozzi, MM \& Davidson, J. (2008). Leadership and Innovation. McKinsey Quarterly, 2008, No I, pp37-47.

BRACZYK, HJ, Cooke, P. \& Heidenreich, M. (Eds). ( I 998). Regional Innovation Systems. London: UCL Press.

BURGELMAN, RA, Christensen, CM \& Wheelwright, SC. (2004). Strategic Management of Technology and Innovation. Asia: McGraw-Hill.

COHEN,WM \& Levinthal, DA. (1990). Absorptive capacity: A new perspective on learning and innovation. Administrative Science Quarterly, Vol 35, pp I28-I52.

DAVIS, J.B., Hands, W and Mloki, U. (1998). The Handbook of Economic Methodology. Cheltenham: Edward Elgar.

DOSI, G. (2000). Innovation, Organization, and Economic Dynamics: Selected Essays. Cheltenham: Edward Elgar.

EDQUIST, C. ( 1 997). Systems of Innovation:Technologies, Institutions and Organizations. London: Printer.

FREEMAN, CH. (1998). The Economics of technical change in D Archibugi \& J Michie (Eds) Trade, growth and technical Change, pp 16-54. Cambridge: Cambridge University Press.
GEE, S. (I98I). Technology transfer, innovation and international competitiveness. New York: John Wiley.

GIBBONS, M, Limoges, H, Nowotny, P, Schwartzmann, P, Scott, $P$ and Trow, W. (1996). The New Production of Knowledge: Dynamics of Science and Research in Contemporary Societies. London: Sage.

HAMEL, G. and Prahalad, C.K. (1994). Competing for the future: Breakthrough strategies for control of your industry and creating markets of tomorrow. Boston Mass: Harvard Business School Press.

HEDLUND, G, \& Nonaka, I. (1993). Models of Knowledge Management in the West and Japan.. In Implementing Strategic Process: Change, Learning and Cooperation. P. Lorange et al., editors. Oxford: Basil Blackwell, I993. Pages II7-I44.

HIVNER, W, Hopkins, SA \& Hopkins, WE. (2003). Facilitating, accelerating and sustaining the innovation diffusion process: an epidemic modelling approach. European Journal of Innovation Management, Vol 6 no 2, pp 80-89.

LAUDON, K.C. \& Laudon.J, P. (2007). Essentials of Management Information Systems: Managing the Digital Firm. 7th edition. New York: Prentice Hall.

LOWENDAHL, B., Revang, O. (2004). Challenges to existing strategy theory in a post-industrial age. Strategic Management Journal, Vol. 19 pp.55-73.

LUNDVALL, BA. ( 1 992). National Systems of Innovation:Towards a Theory of Innovation and Interactive Learning. London: Printer.

McGINN, C. (1996). The Problem of Consciousness: Essays Towards a Resolution. Canada: Blackwell Publishers.

NEEF, D. (1998). The Knowledge Economy. London: ButterworthHeineman.

NONAKA, I \& Takeuchi, H. (1995). The Knowledge Creating Company: How Japanese Companies Create the Dynamics of Innovation. Oxford Blackwell Publishers.

OECD, 1997, 2006, 2007, Science, Technology and Industry Outlook, http://2 I 3.253. I34.43/oecd/pdfs/browseit/930702 I E.PDF [Accessed on 19 February 2008].

PELLISIER, R. (200I). Information Technology - Future perfect? Southern African Business Review, Vol I, no I, pp 66-79. 
PELLISSIER, R. (2007). Research and Innovation Converge or Diverge: Rewiring our corporate brains. The International Journal of Interdisciplinary Social Sciences, Vol 2, no 4.00349-359.

PERSAUD,A, Kumar, U \& Kumar,V. (200 I). Harnessing scientific and technological knowledge for the rapid deployment of global innovations. Engineering Management Journal, Vol I3, no I (March 200I) ppl2-18.

POLANYI, M. (1996). The Tacit Dimension. New York: Anchor Books.

RAVICHANDRAN,T. (2000). Redefining organizational innovation: Towards theoretical advancements. The Journal of High Technology Management Research,Vol I0, no 2 pp 243-274 Elsevier Science Inc.

ROBERTS, ( 1989). Managing invention and innovation. IEEE Engineering Management Review, Vol I7. pp 3-I3.

ROGERS, E. (1995). Diffusion of Innovations. New York: Free Press, 4th ed.

SALMADOR, JAM \& Bueno, E. (2008). Knowledge creation as a dynamic capability: Implications for Innovation Management and Organisational Design. International Journal of Technology Management. Geneva:Vol. 4I, Iss. I/2, p. 155.

SCHNEPP, O, Bhambri, A \& Von Glinow, M. (1987). US-China technology transfer: Problems and solutions. Paper presented at the US-China Symposium Woodrow-Wilson Center, Washington DC,April.

SMITH, D. (2006). Exploring Innovation. McGraw Hill.

SNOW, CC \& Hrebiniak, LG. (1980). Strategy, distinctive competence and organizational performance. Administrative Science Quarterly, 25 pp 317-336.

STRAMBACH, S. (2002). Change in the innovation process: New knowledge production and competitive cities - The case of Stuttgart. European planning studies, vol. 10, no. 2, 2002, PP $2|5-23|$.

TEECE, DJ, Pisano, G \& Shuen, A. (1990). Firm capabilities: Resources and the Concept of Strategy, Working paper 90-9, Consortium on competitiveness and cooperation, Center for Research in Management, University of California, Berkeley.

The McKinsey Quarterly, (2008), number I, Survey, pp I8-23.
THOMAS, RJ. (1995). New product success stories. New York:John Wiley.

VENKATRAMAN, N, Henderson, J.C \& Oldach, S. (1993). Continuous Strategic Alignment: Exploiting information technology capabilities for competitive success. European Management Journal, June, Vol II, no 2, Pp - I49.

WWI, CC. (1997). Managing information for the Competitive Edge. Neal Schumann. 